\title{
SOUTH CHINA SEA CLAIM DISPUTE SETTLEMENT BETWEEN ASEAN AND CHINA
}

\author{
Mohammad Alvian Adi Nugroho, M. Miftahul Hikam. \\ Fakultas Ilmu Sosial dan Hukum Universitas Negeri Surabaya, Indonesia \\ email: ealviano07@gmail.com
}

\begin{abstract}
The title of this research is "South China Sea Claim Dispute Settlement between ASEAN and China" The purpose of this study is to find out the role of ASEAN in efforts to resolve claims in the South China Sea. This research is a descriptive study - analysis that focuses on secondary data. In this study data collection was carried out using the library research method, namely by reviewing several references relating to the problem in this study, as well as interviews with various sources, which were held verbally and frequently asked by informants to get more in the explanation and information about the matter. matters relating to the problems discussed in this study, data obtained from the literature both orally and in writing. territorial conflicts that occur in the South China Sea are increasingly difficult to resolve because the attitude of the Chinese government is often inconsistent with efforts to resolve conflicts offered by ASEAN. ASEAN countries still have not reached an agreement on the Code of Ethics (COC) because of the different interests of each country. ASEAN is expected to face this conflict dynamics while maintaining peace and transforming potential conflicts into potential cooperation through a number of potential peace talks.
\end{abstract}

Keyword: Dispute Resolution, Conflict, Claims, ASEAN, and China.

\section{Introduction}

Currently there are complex dispute problems in the South China Sea, including territorial disputes and maritime boundary disputes, which until now there has been no resolution. Indonesia itself is very careful in dealing with the dispute in the SCS. In the South China sea conflict, in addition to the tensions that have occurred due to friction between disputing countries that have not been able to be stopped until now, there are also worsening developments, especially regarding the relationship between the two ASEAN member countries, Vietnam and the Philippines, against China. 
The territorial dispute in the Set Equipment Sea in China actually refers to the territorial sea and land areas in the two islands of Paracel and Spratly. The regional countries involved in the China Sea conflict in general use historical and geographic bases in claiming ownership of the sea area and the two island groups of the Set Equipment Chinese Sea Territory. China, for example, claimed the disputed territory based on the Chinese ownership of the sea area and the two Paracel and Spratly islands since 2000, then the Chinese government claimed to have issued a map detailing China's sovereignty in 1947, known as "Nine Dashed Line".

Likewise, the Philippines, Vietnam, Taiwan, Brunei Darussalam, and Malaysia also claim that parts of the South China sea area are part of the Exclusive Economic Zone (EEZ) of these countries based on a geographic approach recognized by the 1982 international maritime law convention. - countries that are disputing the South China sea conflict are often involved in clashes that involve state military forces. Confrontative efforts to fight for claims over the ownership of the South China sea area further exacerbate and disrupt the stability of the region, and even have the potential to disrupt the interests of countries around the region that are not directly involved in the South China sea conflict such as Indonesia and ASEAN member countries. (Maksum, 2017, p. 2-3)

There are two aspects that make the South China Sea and the Spratly Islands important, as follows:

1. Strategic Location.

The South China Sea is an important area because of its strategic position as a trade shipping route and international communication route connecting the Indian Ocean and the Pacific.

2. Natural Resources. 
The natural wealth in the spratly archipelago is very large. It has a large oil and natural gas content. It has oil and natural gas reserves of 17.7 billion tons, or in other words bigger than the oil reserves owned by Kuwait (13 billion tons).

These two factors are rational reasons that cause the South China Sea area and the Spratly Island to become a dispute between the 4 ASEAN countries (Philippines, Vietnam, Taiwan, Brunei Darussalam, and Malaysia) and China. (Ninghsih, 2016, p. 3)

In response to this, Indonesia together with other ASEAN member countries are trying to improve communication through diplomacy to neutralize the situation and then be able to rebuild relations in a more harmonious direction. This is the time when ASEAN's solidarity as a regional organization is being tested in order to apply regional norms and customs, such as multilateral engagement. Seeing the geographic proximity of Indonesia and China, it is very important geopolitically for these two countries to establish good relations even though on several occasions China has not touched on the issue of overlapping regional claims with Indonesia. (Megawati, 2018, p. 3)

Meanwhile the Indonesian government affirms its official position in addressing the South China sea conflict. Indonesia will remain in the position of mediating between countries in conflict or dispute over the region. Indonesia will push for the achievement of the Code of Conduct (CoC) between ASEAN and China regarding the region. (Pudjiastuti, 2015, p. 10) To determine whether or not there are overlapping claims between Indonesia and China in the SCS, it is necessary to clarify claims by China. It should also be borne in mind that Indonesia does not recognize China's claims that are displayed on the nine-dashed line. In one statement, in 2009 to the United Nations, Indonesia emphasized that China's claim had no international basis and was a violation of the 1982 UN Convention on the Law of the Sea (UNCLOS). (Nainggolan, 2013, p. 10)

In the case of the SCS dispute, China's unilateral claim to the waters of the SCS based on the nine dashes line law has generated an opposing response from other countries, especially by countries that have similar claims and feel that their 
territorial sovereignty is being violated by China. The majority of countries in the world recognize and use the 1982 UN Convention on the Law of the Sea (UNCLOS) as a legal basis for determining the boundaries of their territorial waters, while China uses the nine dashes line law which is their own creation. (Sakti, 2016, p. 13).

\section{Research Methods}

Research methods are procedures and methods of collecting and analyzing so that the conclusions drawn meet the requirements of systematic thinking. To provide convenience in conducting research, the author will use research methods which are:

1. Analytical Descriptive Research Methods. This research method aims to describe or explain events and occurrences that exist in the present. This method is a method that seeks to collect, to organize, and to interpret data which is then submitted by analyzing the data or analyzing the phenomenon as well as a method of examining an object, a condition, a system of thought or a class of events in the present.

2. Historical Method, The historical method is a research method that aims to make a systematic and objective reconstruction of the past. It uses a way of collecting, evaluating, verifying, and synthesizing evidence to support facts in order to obtain strong conclusions. It aims to test hypotheses related to the causes, effects or development of events that might help, by providing information on current events and anticipating future events. With this historical method, researchers want to find facts about the root of the conflict from the SCS (South China Sea) claim dispute.

This journal was created to determine the role of ASEAN in resolving conflicts in the South China Sea.

\section{Discussion}

The South China Sea borders Taiwan and several member countries that are members of ASEAN (Association of Southeast Asian Nations). Geographically, this area has a strategic meaning, both in terms of the importance of shipping traffic lanes; political, defense and security aspects; or from an economic aspect in the form of a wealth of natural resources in that region. In the aspect of shipping traffic interests, 
this area is one of the most important shipping and trade routes in the world. For political, defense and security aspects, this area is also an important location for transit and operational areas for military ships and aircraft. The aspect of natural resources in the form of the continental shelf area contains oil and gas resources. Several exploration activities proved the large amount of oil and gas content, through submarine pipes and cables. The exclusive economic zone (EEZ) in the South China Sea also contains many fishery and other biological resources (Junef, 9, 2018, p. 4).

The South China Sea dispute has actually been going on for more than 20 years, since 1974. The tensions that have occurred have raised concerns in the ASEAN region and increasingly threaten the world security. The point of dispute in the South China Sea is the Spratly Archipelago, a dispute over ownership of the Spratly Archipelago and the Paracel Archipelago has a long history and borders the territorial waters of several countries, such as the Philippines, Vietnam, Indonesia and Malaysia.

This table describes territorial disputes in six archipelagic regions in the South China Sea and claimant countries in dispute. In addition to the disputed areas above, several countries around the South China Sea have also disputed the 9 dashed lines issued by China in 1949, which cover about $90 \%$ of the total area of the South China Sea and are seen as historical evidence supporting China's claims in the South China Sea. (Junef, 9, 2018, p. 9).

\begin{tabular}{l|l|c|l}
\hline No & Countries & Years & \multicolumn{1}{c}{ Basic Demands } \\
\hline 1 & China & 1887 & $\begin{array}{l}\text { China made demands based on historical records } \\
\text { dating back to the Han dynasty, and this was clarified } \\
\text { in 1887. } \\
\text { The Nationalist Chinese government also made } \\
\text { demands based on history dating back to the Han } \\
\text { dynasty and clarified in 1933. } \\
\text { Vietnam put forward its demands on the Spralty } \\
\text { Archipelago based on history, namely the acquisition } \\
\text { of Emperor Gea Long in 1802 who then merged it } \\
\text { with Vietnam in 1932. }\end{array}$ \\
\hline
\end{tabular}




\begin{tabular}{l|l|l|l}
\hline 4 & Filipina & 1946 & $\begin{array}{l}\text { At the UN General Assembly session in 1946, the } \\
\text { Philippine foreign minister issued a statement that } \\
\text { the Spratlys were handed over by Japan to the } \\
\text { Philippines. } \\
\text { In 1979, Malaysia published a map of the Malaysian } \\
\text { Continental Shelf which contained a portion of the } \\
\text { Spratly Islands. } \\
\text { Brunai protested against the content of the } \\
\text { publication of maps of the Malaysian Continental } \\
\text { Shelf in 1979, and filed a claim against Louisa Reef as } \\
\text { an area located on the Continental Shelf and the } \\
\text { Brunei EEZ. }\end{array}$ \\
\hline
\end{tabular}

Several claimant states have interests in the South China Sea region, and China is the most assertive and aggressive country in the South China Sea conflict, both through the use of diplomacy and sea power (fishing vessels, military patrol boats, and the navy) (Junef, 2018, p. 8). The mechanism in UNCLOS is difficult to implement because two other parties, China and Taiwan, have not made claims on the basis of UNCLOS. From the provisions of Article 33 paragraph (1) of the UN Charter, it can be seen that arbitration is a way of resolving international disputes that its existence has been recognized by the international community. Even if the history is drawn, arbitration is the first mechanism and is the pioneer of the emergence of a permanent court mechanism. The possibility of resolving maritime disputes through an arbitration mechanism is seen in article 279 of the 1982 Law of the Sea Convention.

\section{Role of ASEAN}

ASEAN as an organization that protects the interests of its member countries is trying to find ways to resolve disputes in the South China Sea. Various attempts have been made but have not yet reached a point of completion. ASEAN Regional Forum is a forum to discuss and negotiate problems that exist in the Southeast Asian region. The interests of the ASEAN Community (especially APSC and AEC) in the South China Sea region in accordance with the objectives of the ASEAN Political-Security 
(APSC) and the ASEAN Economic Community (AEC) are enhancing peace, stability, democracy, and welfare (prospority) in the region through comprehensive political and security cooperation. APSC promotes resistance to aggression or use of armed forces or other acts that are not in accordance with international law and is concerned with peaceful dispute resolution. In this regard, APSC upholds the existence of ASEAN political instruments, such as the Declaration on the Zone of Peace, Freedom and Neutrality (ZOPFAN), the Treaty of Friendship and Cooperation in Southeast Asia (TAC) and the Treaty on the Southeast Asian Nuclear Free Zone (SEANWFZ) which play an important role in an effort to build mutual trust (conidence building measures / CBMs), preventive diplomacy, and a peaceful approach to conflict resolution and to address non-traditional security issues. ASEAN and China should carry out the following three actions to maintain peace and stability. First, ASEAN and China must strengthen mutual trust. China suspects that several ASEAN member countries have ignored or even facilitated America's policies that are flickering in Asia (one of the Obama administration's foreign policies) and involving America in the South China Sea conflict. On various occasions China reminded ASEAN to "take no position" in regional power plays

ASEAN and China should work harder to strengthen the principles of a lawbased order in the South China Sea, especially the 1982 UNCLOS. China and ASEAN both agree that UNCLOS is the basis for the creation of a legal order in the South China Sea. China said it was "very important to maintain the principles and goals of UNCLOS." ASEAN calls for "full respect for generally accepted principles of international law, including the 1982 UNCLOS" (Principle number 4 of ASEAN's Six Principles on the South China Sea). However, there were many differences that became evident in the process of interpreting, implementing and implementing UNCLOS which led to a number of incidents of misunderstanding between the parties to the dispute. China's claim to "historical rights" to the South China Sea is an example. China insists that these "historical rights" exist even if China co-signs the UNCLOS, (Article 14 of the Exclusive Economic Zone and Continental Shelf Act (26 June 1998) which states that "this rule will not affect the historical rights of the People's Republic of China").

The South China Sea is also a maritime lane that is passed by international trade shipping and is a source of fishing for fishermen from China, the Philippines, 
Vietnam and others. Because there are so many natural resources that are very strategic and the ownership of this area is very blurred, the actions of mutual claims by countries create a separate conflict in the dynamics of international relations. Thus, this region becomes a struggle for economic, strategic and political interests by these countries. The conflicts that occur are not only bilateral in nature, but become multilateral conflicts, including conflicts caused by non-government actors who take advantage of the exploration and exploitation of natural resources in the South China Sea. The struggle for territory is not only focused on reasons of natural resources such as oil, gas and world food sources, which are 1/10 of the world's total fish catch, but also reasons for sovereignty over areas that have been contested for thousands of years (historical claims) and have become the pride of the past that China, Taiwan and Vietnam wanted to defend. The main basis for the claim to the South China Sea area actually only consists of two aspects, namely historical (historical) and legal aspects. When viewed from the historical aspect, only three countries claiming to use this basis, which are China, Taiwan and Vietnam. For China, it began with the National Government of Chiang Kai-Shek in 1947, which established nine interrupted marks covering almost the entire area of the South China Sea. This was reiterated by Zhou En-Lai who asserted his claim to the territory in 1951, but in his claim, China did not explain the legal aspects of its maritime boundary delimitation. Maritime territorial dispute resolution can only be done based on international law or UNCLOS 1982, however these historical claims are not recognized in UNCLOS. In this applicable international law the principle of "uti possidetis juris" is recognized.

This terminology is historically derived from Roman law which meant that the territories and other assets that followed the original owner at the end of the conflict between the new state and the previous ruler were presented in a treaty. The use of this principle according to some international legal experts, such as Paul R. Hensel Michael E. Allison, and Ahmed Khanani, will create more stability on the border than the borders of countries that were not inherited by the invaders. The reason was, that the colonial rulers had laid the foundations of state boundaries clearly in an agreement, so that the newly independent countries from the colonial powers had only to carry on the border legacy left by the colonialists. So the main purpose of using this principle is to prevent conflicts based on seizure of borders by new countries. (Nainggolan, 2013) The mechanism for implementing the principle of uti possidetis 
in determining the point of reference for land boundaries between countries, in its practical context is carried out by the following steps: at the initial stage both parties agreed to use historical arguments that determine the allocation of border areas that occurred on colonial; then, after the allocation of border areas has been agreed upon, then both parties agree to delimitate, to determine the border line using a convention; Furthermore, after the delimitation has been agreed based on the border convention, the two parties jointly carry out demarcation, that is confirming the border poles as stated in several conventions.

ASEAN and China should undertake the following three measures to maintain peace and stability (Junef, 2018)

First, ASEAN and China must strengthen mutual trust in each other. Second, ASEAN and China should work harder to strengthen the principles of a law-based order in the South China Sea, especially the 1982 UNCLOS. Third, China and ASEAN must immediately work to draft a Code of Conduct that is binding in the South China Sea.

In a press briefing at the Philipines International Convention Center (PICC), the Minister of Foreign Affairs of Indonesia, Retno Marsudi, said, "We have adopted the $\mathrm{CoC}$ framework, which is an advancement between us and China to adopt the $\mathrm{CoC}$ framework". In a bilateral meeting with Chinese Foreign Minister Wang Yi on the same day, Retno also expressed her appreciation for the constructive involvement of the Bamboo Curtain country.

\section{Conclusion}

ASEAN and China should work harder to strengthen the principles of a lawbased order in the South China Sea, in accordance with the legal basis of the 1982 UNCLOS. China and ASEAN both agree that UNCLOS is the basis for the creation of a legal order in the South China Sea. China said it was "very important to maintain the principles and goals of UNCLOS." ASEAN calls for "full respect for generally accepted principles of international law, including the 1982 UNCLOS" (Principle number 4 of ASEAN's Six Principles on the South China Sea). However, there are many real differences in the process of interpreting, implementing and implementing UNCLOS which have resulted in a number of incidents of misunderstanding between the parties to the dispute. China's claim to "historical rights" to the South China Sea is an 
example. China insists that these "historical rights" exist even if China co-signs the UNCLOS, (Article 14 of the Exclusive Economic Zone and Continental Shelf Act (26 June 1998) states that "this rule will not affect the historical rights of the People's Republic of China. ").

Because the South China Sea is part of a strategic international area and has great influence as an international trade route and refers to the International Law of the Sea (UNCLOS 1982), the solutions are

1. As a disputed region by several ASEAN countries and China which both ratified and signed the 1982 UNCLOS, China must comply with the applicable rules.

2. Creating a Code of Conduct ( $\mathrm{CoC}$ ) agreed upon by the claimants of the area to avoid open conflict in the area.

\section{Acknowledgments}

Thank you to God Almighty for launching our journal. And we would also like to thank our supervisors, including Elizabeth Puspoayu, Irfa Ronaboyd, and Peni Jati for his time and all his guidance in making this journal. And do not miss my friends who give encouragement in working on journals, I say many thanks.

\section{REFERENCES}

Dewi, C. (2017). ASEAN - Tiongkok Adopsi Kerangka 'Aturan Main' Laut China Selatan. https://www.liputan6.com/global/read/3048743/asean-tiongkok-adopsikerangka-aturan-main-laut-china-selatan

Junef, M. (2018). Sengketa Wilayah Maritim Di Laut Tiongkok Selatan. Jurnal Penelitian Hukum De Jure, 18 (2), p. 229-231, https://ejournal.balitbangham.go.id/index.php/dejure/article/view/420, DOI https://ejournal.balitbangham.go.id/index.php/dejure/article/view/420

Maksum, A., (2013) Regionalisme dan kompleksitas laut china selatan. Jurnal Sosial Politik, 3(1), http://ejournal.umm.ac.id/index.php/sospol/article/view/4398, DOI: https://doi.org/10.22219/sospol.v3i1.4398 |

Megawati, U. \& Arundhati, G.B. (2018). Dinamika Sikap Tiongkok atas Putusan Mahkamah Arbitrase Tetap Internasional Nomor 2013-19 dan Pengaruhnya Terhadap Indonesia, Lentera Hukum, 5 (1), 
https://jurnal.unej.ac.id/index.php/eJLH/article/view/6553,

DOI: https://doi.org/10.19184/ejlh.v5i1.6553

Nainggolan, P. P, (2015) Konflik laut china selatan dan implikasinya terhadap kawasan,

Pusat Pengkajian, Pengolahan Data dan Informasi (P3DI) Sekretariat Jenderal

DPR Republik Indonesia,

https://berkas.dpr.go.id/puslit/files/buku tim/buku-tim-public-25.pdf

Ninghsih, O. A. (2016). Sengketa Kepemilikan Spratly di Laut China Selatan

Berdasarkan UNCLOS III 1982. Jurnal Online Mahasiswa, 3 (2),

https://jom.unri.ac.id/index.php/JOMFHUKUM/article/view/12795/0

Sakti, Zeny Caturandy Wibowo 2016. Peranan ASEAN Dalam Mengatasi Klaim Laut China Selatan Oleh RRC. http://repository.unpas.ac.id/12674/

Yoon, S. (2012). Chinese minister: Asean can shape power play in E Asia. http://www.nationmultimedia.com/politics/Chinese-minister-Asean-canshapepower-play-in-E-A-30184834.html 